\title{
Local Wars Threatening World Peace
}

\author{
Jan Pilzys" \\ The University of Szczecin, Department of Humanities \\ The Institute of Politics and European Studies, Department of Peace Operations and Reacting in Crisi, ul. \\ Krakowska 71/79, 71-017 Szczecin \\ *Corresponding Author: Jan Pilzys, The University of Szczecin, Department of Humanities, The \\ Institute of Politics and European Studies, Department of Peace Operations and Reacting in Crisi, ul. \\ Krakowska 71/79, 71-017 Szczecin, Poland
}

\begin{abstract}
The task of the author of the article is to show that the society and the achievements of civilization are the basic point of reference to the phenomenon of war. It is those that strongly influence the contemporary political, social and military realities. They can start, deepen or end every bloody conflict. Each of them is very complex and at a given moment, in many parts of the world, it causes casualties and causes huge material losses. In the author's opinion, the emergence of new and continuation of old conflicts depends on several conditions, i.e. the disproportions and weaknesses of states' potentials, the inability to exercise efficient control of those in power over their own territory and population, lack of respect of those in power towards the sovereign, the operation of bad international law, the mixing of cultures and religions - resulting in the disintegration of states and their civilizations.

The above conditions are not the only ones that lead to a conflict within states, with other states or between religions - called religious wars. The escalation of conflicts causes their transformation into a war that draws others in, causing destruction and fear of an uncertain future. According to the author, the helplessness of societies, including state and world institutions, does not mean the disappearance of survival. Therefore, the author hopes that by his reflections, observations, he will contribute to changing the way of thinking of decision-makers about war, which is not the final solution to problems. The author refers to other publications in which issues related to the causes of wars and methods of preventing them are addressed. In the article, much attention is devoted to the efforts made to maintain world peace.
\end{abstract}

Keywords: Security, threat, war, peace, society

\section{About War And Its Causes}

According to the author, war and its causes should be discussed and written about, showing the people concerned the problems and ways to solve them. It must be made clear that the enormity of modern threats arises as a result of ill-considered human activity. Therefore, there is a need to control them. We need to prepare world opinion against all propaganda manipulation - that something is threatening us, and thus there is a need to militarize the state and transfer huge sums to armament programs. Such activities do not lead to anything good.

Nowadays, communities with increased sensitivity should definitely oppose the above actions through massive protest actions to maintain security and peace in the world, which stands over the abyss, i.e. the "limit of nuclear killing", which must not be exceeded. According to the author, it is necessary to consider how to overcome the ideological and political contradictions of states that underlie the distrust as to their intentions in diplomatic talks. They are extremely difficult to solve and are deepening. Proof of this are the tensions and disputes in international relations caused, among others, by the lack of raw materials, jobs, mass migrations, armed incidents, wars. Each of them causes sociopolitical crises that cause conflicts that transform into armed confrontations and wars. The latter are the most dangerous and unpredictable, deviating from the current image of wars (classical), i.e. currently ongoing - asymmetric and hybrid wars ${ }^{1}$. So it is justified to be concerned and ask, what's

\footnotetext{
${ }^{1}$ L. Wyszczelski, Visions of wars after the disintegration of the bipolar political and military system of the world, [in:] " Bellona Quarterly", 2016, No. 1 (684), pp. 97-105.
} 
next? What will our future be like in the world of armaments and ongoing conflicts and wars? Will the brakes banning warfare work?

This concern is expressed by Professor Lech Wyszczelski specializing in the history of military, military thought history and war theory. In his article, he writes that "today there is no reflection on long-range visions of wars"2. He asks himself and us questions ${ }^{3}$ : "Is there lack of imagination? Or maybe it is the result of a civilizational leap and fears of the emergence of combat means that it will destroy previous constructions? "He adds," that today's catalogue of the latest war theory has not been exhausted"4.

According to the author of the article, today's conditions for conducting wars in the world mostly differ from mass classical wars. Therefore, today's strategists should think prospectively. As Lech Wyszczelski writes, "the knowledge of known war theories seems necessary to capture changes in both theoretical reflection and war doctrines as well as military organization". Such strategic, operational and tactical thinking should take place much earlier, when the bipolar political and military system of the world broke up. One gets the impression that military strategists and those of civilian institutions guarding the security, are stuck in one place, are still surprised by what is happening around them, as if they lacked a link (element, center) of the analytical security environment of the state, including military threats. This situation requires immediate solutions to adapt the defense potential to threats, especially the military potential in the state's defense system to the new face of wars.

The subject of the war, its causes, was undertaken by the author in the article, War and military doctrine in the military thought of 1921-1939 and Civilizations in the shadow of nuclear weapons ${ }^{7}$. The first article includes the more important views of theoreticians of military thought (Władysław Sikorski, Carl von Clausewitz, Jan Bloch, Marian Jurecki, Stefan Mossor, Tadeusz Zakrzewski and others) on the essence of the war, its preparations, conduct and consequences in the analyzed period. The second one shows the observations (Joseph Samuel Nyje Jr., Feliks Koneczny, Samuel Huntington, Edward Haliżak, Henry Kissinger, Zbigniew Brzezinski, Alvin and Heidi Toffler, Irena Popiuk-Rysińska, Andrzej Dawidczyk, and Ireneusz Białkowski) on the construction of a political, military and economic order in the world, in the post-war years up to the modern times.

According to the author, the quoted views of well-known figures are worthy of reminder and reflection. This applies to their assessment of major cultural, military, economic and religious conflicts in the contemporary world, which, nowadays, instead of decreasing, grow with double strength, may lead to another world war.

In order to fully implement the subject of this article, reference should be made to several of the previously cited articles. This will allow the author to create a fabric of the picture of the future war and its effects, i.e. showing the likely causes of its triggering, waging and effects on the human environment.

In the interwar period, the view was accepted that war ceased to be a war of armed forces and became a war of nations. The search for organizational forms involving modern national defense was initiated $^{8}$. Thus it would cover not only the armed forces, but all areas of the nation's life. To a large extent it would depend on the cooperation of civil authorities with the military, joint preparation of mobilization of the economy in the event of war and the broadly understood security system. Such a state of affairs would have an impact on maintaining the combat readiness of the fighting troops and the survival of the population, as well as the internal peace and efficiency of government. This, in

\footnotetext{
${ }^{2}$ Ibidem, pg. 110.

${ }^{3}$ Ibidem.

${ }^{4}$ Ibidem, pg. 92.

${ }^{5}$ Ibidem, pg. 92-93.

${ }^{6}$ Scientific Papers of the Military Academy of Land Forces, Wrocław, 2012, No. 2 (164), p. 206.

${ }^{7}$ M. Bodziany, Society and War. Faces of security in the XX and XXI century, Wrocław 2016, pg. 259.

${ }^{8}$ W. Sikorski, Future war, its possibilities and character, and related issues of the defense of the country, Warsaw 1984, ed. II, pp. 89-90; R. Jakubczak, J. Flis (ed.), National Security of Poland in the 21st Century. Challenges and strategies, Warsaw 2006, pg. 227-230.
} 
turn, was supposed to create optimal conditions for the army for fighting an armed conflict. Therefore, in order to succeed in the fight and to bear as little human and material losses as possible, it was suggested to the authorities at that time, to spare no expenses in the times of peace for the defense of the nation, including the army and supplies necessary for warfare.

The above-mentioned issues lead to practical solutions to the issues of war with the unity of the army and the nation. It is a thesis and practice known for a long time, it is known the army and the nation stand together to fight with the potential enemy.

War was the most general category in the art of warfare, in classical terms - according to Carl von Clausewitz, it was a political act, a continuation of political relations expressed in the act of violence, while the immediate goal of warfare was to disarm the enemy, that is, bring their armed forces to the state in which they will not be able to continue fighting. It was believed that during peacetime, the whole life of the nation must be directed towards conducting total war ${ }^{10}$, with special emphasis on the upbringing of society, economic organization, preparation of the army and diplomacy ${ }^{11}$.

Jan Bloch in his publications (in the nineteenth century), predicted the effects of a possible clash of European powers ${ }^{12}$. He argued in them that: "The political, economic and psychological factors that govern civilizational societies are based on the strength of the army. War is the foundation and the axis of their existence" ${ }^{, 13}$. He claimed that the war of the future would be of a global and destructive nature using all available techniques. The future military clash will outstrip previous wars. He predicted that rifles, artillery and aviation would be the decisive weapons on the battlefield. On the other hand, cavalry charges and bayonet attack will become impossible against their firepower. $\mathrm{He}$ warned that the evaluation of the war and technical side of the course and results of military operations was not enough, he paid attention to the economic and social consequences of warfare. He mentioned war plans that "the winner would be the one who manages to conduct military operations in accordance with their own plans prepared in advance, in other words, to engage the opponent in a fight in conditions and circumstances unforeseen and unrelated to their own plans and projects"14.

In the interwar period, the causes of wars could be: economic struggle, expansion, possessiveness, conflict of hostile alliances and struggles of a revolutionary or liberation character. According to the marshal Józef Piłsudski "War was an exam not only for the army but also for the entire machine of the state ${ }^{15}$. He believed, as in fact many theoreticians and practitioners of thas period, that, no war is similar to the previous one ${ }^{16}$.

In the second article Civilizations in the shadow of nuclear weapons, the author defined the concept of civilizations, defined their number, manner of formation, duration and survival. According to the author, the phenomenon of a security crisis affecting nations and their civilizations is becoming more dangerous. Many natural, civilization and anthropogenic hazards arose, which reduce the level of development of societies - ranging from cultural and armed conflicts, dangerous viruses, lack of water and food to the use of nuclear weapons. These are global problems, growing with great strength, which must not be underestimated.

An example of this are the events that take place, among others in Syria, South Sudan, Libya, Iraq, Turkey, Israel, Ukraine, Germany, France, Belgium, Sweden and Greece. There are more and more of them and they are shocking, and worst of all - we've started to live with them - get used to them because on the face of it they do not seem to concern us.

The existing political, military, economic and religious situation in the world is increasingly threatening the entire population. Especially worrying is the powerlessness of people at the helm of

\footnotetext{
${ }^{9}$ Carl von Clausewitz, About war, cz. I, [Book 1-5], Warsaw 1958, pg. 15-50.

${ }^{10}$ B. Chocha, J. Kaczmarek, War and military doctrine. Selected problems, Warsaw 1980, pg. 116.

${ }^{11}$ S. Mossor, The presumed nature of the future war, "Bellona", 1936, n. 1, pg. 92-93.

${ }^{12}$ J. G. Bloch, Future war in technical, economic and political terms, Warsaw 2005.

${ }^{13}$ Ibidem, pg. 15.

${ }^{14}$ Ibidem, pg. 191.

${ }^{15}$ H. Smaczny, Polish armed forces 1919-1939, Białystok 1999, pg. 197.

${ }^{16}$ Ibidem.
} 
power, characterized by a lack of ideas to solve accumulated problems at the national and global levels. Instead of solving them together - countries begin to fight each other, lying to their societies, preaching populist slogans, in line with their expectations and not those of ordinary people. Some of them destroy peaceful solutions to conflicts, by their actions endanger peace in the world - threatening the use of nuclear weapons ${ }^{17}$.

The above proves that so far there is no single, coherent theory that captures the anticipated shape of the international social order ${ }^{18}$. And this is because it is a dynamic process, having a turbulent course in the life of societies, whose goal is mostly to protect and at the same time increase a certain state of ownership, based on its own potential of national security or of international alliances. National states are still the main actors of the international scene, grouped in the main military and economic blocs. For a long time, we have been observing the grouping of states around specific cultural centers, and these are usually religious centers. According to Samuel Huntington, they will shape patterns of cohesion, disintegration and conflict in the world. We have more and more of them, they are intensifying and are more dangerous than ever in the past. They have become more intense, continuous and multidirectional, more and more often of anarchic character (arbitrary, undisciplined) in many cases - leading to fratricidal struggles for maintaining power within a given country and escalation of conflict between states of a given bloc or between cultural centers including using weapons.

In order to bring closer the above problems of civilization and their security, well-known world publicists shared their insights, including Henry Kissinger. In his publications, he observes that for a long time, the grouping of states around specific cultural centers has been observed, and these are usually religious centers ${ }^{19}$. Zbigniew Brzeziński, on the other hand, showed the historical dimensions of the US-Soviet conflict, the main spheres of competition for domination over Eurasia and military capabilities, including the use of nuclear weapons ${ }^{20}$. He drew a brave thesis that Russia's advantage in conventional arms in this part of the world and the awareness of the lack of US nuclear interference may lead to unpunished military aggression, political intimidation and the inhibition of international cooperation for common security. We further read that the Russian Federation has become a state that is able to destroy, to tear apart the world order, but it is not able to rule.

Alvin and Heidi Toffler in their publication made observations regarding the future of international order, inter alia $^{21}$ : they display dangers connected with uncontrolled progress of science and technology, economy and civilization, which in the future will constitute a psychophysical and physical barrier of human adaptation to rapid changes in their environment, i.e. characterized by ephemeral nature, novelty and diversity. They write about the future of the wealth of humanity, which, if properly managed, can change life and the world for the better. The essence of their theory is a civilization tripartite, based on ways of acquiring goods.

From the above it appears that in disputes between civilizations (blocks) the main role will be played by nuclear weapons, energy resources, currently - according to the author of the article "immigration weapon", understood as hundreds of thousands of people getting from the African continent thus disorganizing the functioning of countries belonging to the European Union. The purpose of such action may be to divert attention from the goals of the belligerent countries in the world. It can also be supposed that at present we are dealing with the inter-civilizational clash of African civilization with

${ }^{17}$ G. Dworkin, Nuclear intentions, [in:] T. Żuradzki, T. Kuniński (ed.), War ethics. Anthology of texts, Warsaw 2009, pg. 259-276, C. W. Morris, Contractual defense of nuclear deterrence, [in:] T. Żuradzki, T. Kuniński (ed.), War ethics ..., 277-296.

${ }^{18}$ See more in: S.P. Huntington, Collision of civilizations, (translated by H. Jankowska), Warsaw 2007; J. S. Nye jr., International Conflicts. Introduction to theory and history, Warsaw 2009; E. Haliżak, Interdependence of politics and economics in international relations, [in:] E. Haliżak, R. Kuźniar, G. Michałowska, S. Parzymies, J. Symonides and R. Zięba (ed.), International relations in the XXI century. Anniversary book in the event of the 30th anniversary of the Institute of International Relations at the University of Warsaw, Warsaw 2006.

${ }^{19}$ H. Kissinger, Diplomacy, Warsaw 2009, same: Crisis: Anatomy of two crises, Wrocław 2005, About China, Czarne, Wołowiec 2014.

${ }^{20}$ Z. Brzeziński, Game plan. USA - USSR, Warsaw 1990, same: Great chess board, Warsaw 1999.

${ }^{21}$ A. Toffler, H. Toffler, Revolutionary wealth, Przeźmierowo 2007. 
the Western European one, which according to Feliks Koneczny, quoted by Leszek Gawor, aimed at the mutual civilization "exhaustion". As a result, neither side will be the winner, one cannot be civilized in two ways at the same time ${ }^{22}$.

At present, the tendency of European states to increase their armed forces is visible. More and more funds are being spent for this purpose. Such action leads to excessive impoverishment of budgets and, hence, societies. The question should be asked, Is this action necessary?

At present in Europe, almost every state belong to an alliance ${ }^{23}$, at least one or more of them have nuclear weapons. As of today, they are a protective umbrella for countries that do not have this weapon. And here new questions arise whether such a state will use this weapon against the state threatening the alliance, will it not hesitate? We know from history that allies did not keep their agreements, what then - the country being attacked must defend itself, waiting for someone to come to its aid.

Hence the conclusion that every state belonging to the alliance should have its own defense system, including armed forces ready for war. The only question is to what war - conventional, conventional war using tactical nuclear weapons or nuclear war? Are they likely in today's conditions? Will it be possible to achieve the goals of the war by an aggressor and the defender? What consequences will the countries taking part in it have? Some of these questions cannot be answered unambiguously.

From time immemorial, the issue of peace and war for nations was a matter of life or death. Until today, wars have constituted an important part of the history of war, especially war science and its art of war, shaping the image of contemporary armed struggle and war in its entirety. They bring new experiences that can be used by strategists in the next wars. Therefore, there is a need to refer to the most outstanding minds of past centuries and epochs in this matter.

It is impossible to disagree that war is the most terrible disaster and the greatest vice of wars, as genocide, will be counted among those extraordinary atrocities that humiliate and violate human nature, that insult the country and the epoch, tainted with the greatest of crimes ${ }^{24}$. According to Fryderyk Hegel and Clausewitz, war is a political act, a tool of policy that wants to resolve the conflict with the help of armed forces ${ }^{25}$. Do politicians bear the greatest blame for each of the wars? Do not they see that abuse of power is not profitable. The examples are Afghanistan, Georgia, Ukraine, Syria, Libya, South Sudan. Abuse of power leads to poverty and the extermination of population, material heritage, monuments of world cultural heritage ${ }^{26}$. In many cases, there are genocides, crimes against humanity or war crimes, not only committed by the aggressor, but also by internal forces. Since 1945 there have been about 160 wars and internal conflicts, some of them are still in progress. They have absorbed tens of millions of lives ${ }^{27}$. Such activities are subject to the jurisdiction of the International Court of Justice in The Hague. According to the author, the United Nations Security Council does nothing about it. What steps are taken by the European Court of Human Rights on this matter? How can such state of affairs be justified? Probably law and order in the international community have been shaken and are drifting towards the "World War". There are

\footnotetext{
${ }^{22}$ L. Gawor, Feliks Konieczny's study of the multiplicity of civilizations, "Sofia", 2005, No. 5, pg. 91-93.

${ }^{23}$ B. Chocha, J. Kaczmarek, War and doctrine ..., pg. 82-91. According to the authors of the publication, the word "coalition" contains in itself the concept of strength, and at the same time the immanent concept of weakness. It is a very complicated phenomenon, and the reason is the differences occurring among the coalition partners in the wartime-economic potential and in the actual political and ideological goals. These causes trigger weaknesses, and hence discrepancies as to the nature and ways of preparing and conducting a war.

${ }^{24}$ J. G. Bloch, Future war in technical, economic and political terms, Warsaw 2005, pg. 80

${ }^{25}$ Z. Kuźniar, K. Barczyk, The phenomenon of war from the point of view of the dialectical philosophy of G.F. Hegel, [in:] M. Bodziany (ed.) Society and war. Faces of security in the XX and XXI century, Wrocław 2016, pg. 385-387; B. Balcerowicz, About peace and war. Between an essay and a treaty, Warsaw 2013, pg. 83, A. Makowski, Maritime Wars - methodological problems, [in:] A. Aksamitowski, M. Franz (ed.), From the History of marine wars. Studies and sketches, Oświęcim 2015, pg. 14.

${ }^{26}$ J. Pilżys, System of security of monuments and national heritage of the Republic of Poland, [in:] J. Piątek, R. Podgórzańska (ed.) Selected aspects of security, Volume I, Szczecin 2007, pg. 251.

${ }^{27}$ See more in: A. Toffler, H. Toffler, War and anti-war, how to survive on the threshold of the 21st century, Warsaw 1997.
} 
many indications that international law loses its relevance in the era of the United Nations Organization and other organizations, such as the Organization for Security and European Cooperation or the African Union, is vulnerable and unstable. It lacks an adhesive - authority, a joint force (international police) forcing its observance ${ }^{28}$.

I agree with Michael Walzer that "lawyers have created a paper world at crucial points not matching the world in which we live"29. Its structure breaks and threatens with disaster of the whole structure and only because one of the countries breaks out defending its own interest. Therefore, it is our duty to organize a new system prohibiting such practices, stopping regimes and global terrorism. These must be rapid measures preventing the spread the stratifying problems of states without the horrific devastation of war.

\section{ASSESSMENT OF A WAR}

The phenomenon of war and peace between nations has long been of interest to history, social sciences and its related sciences. Questions have been asked in them about their meaning for the human condition, on an individual and social scale. Places of war for the sake of the state's stability in international relations and ways of maintaining peace. We can see these problems in every work in this field, from antiquity to the present day, and in them, definitions of war, which was understood as:

- The biggest matter of the state, which is the basis of life and death. ... survival or doom ${ }^{30}$,

- illness, and its conduct, according to the Greek historian Thucydides (about 460 - about 396 BC), released the worst instincts, striking at the basic social ties ${ }^{31}$

- destroying the attacked state, including it in one's own territory or leaving its existence on the basis of subordination to one's own government ${ }^{32}$

- a just fight with the help of public armed forces ${ }^{33}$

- $\quad$ waging it to make peace, ... as the ultimate goal, ... is a state of struggle using force as such ${ }^{34}$

- the work of people whose goal is to achieve a better state of peace $e^{35}$

- contradiction of interests, opposing two entities that are not able to co-exist peacefully ${ }^{36}$

- a legal status that allows two or more parties who are conflicted to resolve a conflict with the use of armed forces ${ }^{37}$

- continuation of the policy with the use of violence to force the opponent to fulfill our will; it has the character of a bloody armed struggle, fought by organized armed forces ${ }^{38}$

${ }^{28}$ J. S. Nye Jr., International conflicts ..., pg. 24.

${ }^{29}$ M. Walzer, Just and unjust wars, Warsaw 2010, pg. 27.

${ }^{30}$ Sun Tzu, Sun Pin, Art of War, Edition II, Gliwice 2008, pg. 60. Sun Tzu (544-496 BC) - thinker, strategist of the ancient Far East, author of the Chinese military treaty Art of war.

${ }^{31}$ J. R. Zacharski, War in the modern world. Participants. Objectives. Models. Theories, Łódź 2014, pg. 134.

${ }^{32}$ The definition of war developed by the prominent Italian politician, writer and military theoretician Niccolo Machiavelli (1469-1527), was quoted by L. Wyszczelski, in the article: War and the art of war in the Western European military theory of the sixteenth and seventeenth centuries, " Bellona Quarterly", 2014, No. 3, pg. 86.

${ }^{33}$ The definition of war developed in 1598 by Albert Gentilius, was quoted by L. Wyszczelski, in the article: War and the art of war ..., pg. 92.

${ }^{34}$ The definition of war presented in 1625 by H. Grotius, quoted by L. Wyszczelski, in the article: War and the art of war ..., pg. 92-93.

${ }^{35}$ L. Hart, Strategy. Indirect activities, transl. E. Biegański, Warsaw 1959, pg. 409.

${ }^{36}$ Z. Kuźniar, K. Barczyk, The phenomenon of war from the point of view of philosophy ..., pg. 385.

${ }^{37}$ P. Nowak, Conflict and war in the theory and practice of international relations, [in:] M. Cupryjak, P. Nowak, P. Ostrowski (ed.), Legal and historical approach to war and terrorism, Szczecin 2016, pg. 18-19. The author of the article quotes the definition of war from a publication written by Q. Wright, on A Study of War, Chcago1983, pg. 7.

38 J. Kunikowski, A Dictionary of Basic Terms in the field of defense knowledge, Warsaw 2002, pg. 19, F. Skibiński, Considerations on the Art of War, Warsaw 1978, pg. 29. 
- politics, but implemented by other methods ${ }^{39}$

- social, historical and class phenomenon, consisting in settling disputes or pursuing political goals through the use of violence in the form of armed forces

- a cyclical phenomenon of dispute resolution inscribed in the history of $\operatorname{man}^{40}$

- ethnic or religious activities conducted by groups described as terrorist, bandit or criminal ${ }^{41}$

- catastrophic phenomenon, resulting from the existing anarchy in international relations, which results in the annihilation of humanity or its part ${ }^{42}$

- the phenomenon to avoid, it is no longer necessary, unprofitable, it has only changed its character $^{43}$

- a special form of armed conflict, which comes into being when the specific "demarcation line" is crossed, beyond which armed violence begins, as the main method of politics, and the armed forces constitute one of its many instruments ${ }^{44}$

- one of the areas of human activity and some more or less systematized moral doctrine, which in part, but not entirely corresponds to the binding legal doctrine, ...war is the most difficult situation, hell, the appearance of honesty, ... it is something beyond the sphere of moral judgment, ...it is a separate world, where life itself is at stake, where human nature is reduced to these elementary incarnations, where self-interest and necessity rules, ... deprives us of civilized garments and exposes our nakedness, i.e. fear, selfishness, compulsion, lust for murder and domination ... it is an extreme case of the anarchy of moral meanings, ... it does not put limits in every respect: people die, killed with all imaginable brutality ${ }^{45}$

- action combining the traditional method of fighting with the inclusion of unconventional and cyber weapons as part of a hybrid war, during which there is "preference of indirect and asymmetric methods, combining a whole set of capabilities, both military and other types, aimed at bringing erosion of the opponent's forces, his influence and will ${ }^{46}$

- only a destructive factor, it destroys the established social order, wipes out the output of entire generations and hundreds, thousands of victims ${ }^{47}$

- armed interventions of the peace-enforcement operations nature conducted by multinational coalitions $^{48}$

\footnotetext{
${ }^{39}$ R. Romański, Military errors of Polish commanders, Warsaw 2013, pg. 6.

${ }^{40}$ P. Ostaszewski, International political relations. Outline of lectures, Warsaw 2010, pg. 380.

${ }^{41}$ P. Nowak, Conflict and war in theory and practice ..., pg. 19.

${ }^{42}$ R. Łoś, J. Regina-Zacharski, War in the modern world. Participants, goals, models, theories, Warsaw 2010, pg. 138-139.

${ }^{43}$ P. Nowak, Conflict and war in theory and practice ..., pg. 19.

44 B. Balcerowicz, Peace and "unrest" on the threshold of the 21st century, Warsaw, 2002, pg. 161.

${ }^{45}$ M. Walzer, Just wars ..., pg. 28-49, 65,

46 E. W. Radecki (ed.), Lexicon of education for security, Szczecin 2015, pg. 127; J. Pawłowski, Asymmetry the consequence of turbulent military changes in the sphere of quantity and quality, [in:] Art of war in contemporary armed conflicts - changes and developmental tendencies, Materials from the scientific conference organized on October 20, 2006. Issued by AON in 2017, pg. 39. Professor Pawłowski, in his reflections on new threats - understands asymmetry as an unfair fight, hitting a weak point, information fight, fighting as part of a psychological war, the threat or use of weapons of mass destruction. He further writes on page 43 that asymmetrical threats will be put forward by entities that intend, by using fighting methods different from the usual ways of acting of their opponent, to overcome the advantage (primarily on the military level), hit its weakest points and achieve disproportionate effects greater than the forces involved, see also: P. Gawliczek, Symmetrical, desymmetrical and asymmetrical actions and wars - French and Swiss approach, [in:] Art of war in contemporary armed conflicts ..., pg. 143-149.

${ }^{47}$ P. Chmielarz, War and the state. Yesterday and today, Warsaw 2010, pg. 10.

${ }^{48}$ Ibidem, pg. $273 \mathrm{~J}$.
} 
- an irreconcilable conflict between at least two collective entities, which is characterized by a certain level of self-organization ${ }^{49}$,

- one of the forms of armed conflict, ...war is the turn of epochs, civilization change, progressive globalization and the new international order that is constantly evolving ${ }^{50}$,

- the state of international relations connected with the existence of a conflict in the sphere of vital interests of states, involving the majority of state resources and available forms of action, including the use of extreme forms of violence, ...is the sum of all kinds of struggle and cooperation, it is a category covering the whole state effort, not one of them, even if it was important, such as armed combat ${ }^{51}$.

From the above definitions it can be concluded that war is one of the oldest social phenomena known to mankind. Despite the international ban on the use of force or the threat of its use, it is still an important instrument for the implementation of foreign policy. The whole generation of researchers representing various fields of science has tried to explain the essence of wars and the reasons for their formation. This concept focuses both horror and the feeling of triumph. On the one hand, it signals cruelty, death and loss, on the other hand it contains joy, satisfaction with victory and defeating the opponent $^{52}$. However, as a result, it destroys everything that man values the most - human life.

According to the author, it is necessary to oppose in a rigorous way those who say that war is inevitable and necessary, that it is considered one of the rules of human development. You cannot allow it to be the result of chance, wrong decisions or the pursuit of a "some" politician to gain and retain power. Hence, there must be forces prevailing over ominous propaganda, watching over the maintenance of peace in the world.

The above proves that there are also those who want to build their wealth on state militarism and ongoing wars, paid for by the blood of millions of people. One should oppose blind obedience to those who lead to this, inter alia, ineffective politicians, those in the military and capitalists. They must understand that power and money are not everything that one can lose them quickly and be tried. At present, there is a visible return to nature and equality based on an agreement of those in power with a part of the society. This is nothing but omnipotence that has nothing to do with social justice. History teaches that such an attempt to take away from some and give others encounters the resistance of the former. According to the author, such actions will ruin the idea of civil society, personal property. Only the work given to everyone, combined with the effort, will solve the more important problems of mankind and the world.

In the world of politics, there is a discourse about what is happening around us, about wrong policies, lack of work, uncontrolled migration, armed conflicts, threats of terrorism. Statements of politicians are sometimes unprepared and provocative. They often express opinions harmful to the state and its environment, based on conjecture or gossip, leading to quarrels, fighting for votes. In many cases, this is a manifestation of a struggle for the interests of their party. Such actions should be curtailed, creating a code of conduct or another document setting out the bases (rules) stating about the observance of legal, political, ethical, cultural or religious norms. This should also apply to other community groups, especially their managers in a given case. Is it possible? It certainly is, but how to do it.

Let us return to judgments of war using the previously given definitions. One should start by formulating the thesis that the greatest threat to the world are weakening economic, self-proclaimed authoritarian empires - military forces on clay legs, whose rulers are blinded by the lust for power and money, they ruin the social justice of their nation and the world, divide the population, set one against

\footnotetext{
${ }^{49}$ R. Zacharski, War in the modern world. Participants. Objectives. Models. Theories, Łódź 2014, pg. 134.

${ }^{50}$ B. Balcerowicz, Contemporary Art of war - Contexts, [in:] Art of war in Contemporary Armed Conflicts ..., pg. 129.

${ }^{51}$ R. Szpyra, Art of war and military art in the context of contemporary dilemmas, [in:] Art of war in contemporary armed conflicts ..., pg. 135.

${ }^{52}$ See. F. Ryszka, Politics and war, colloquial awareness and 20th century theories, State Publishing Institute, Warsaw 1975, B. Miśkiewicz, War as the subject of historical research, [in:] K. Olejnik (ed.), War as the subject of historical research, Torun 2006.
} 
the other, pushing them to fight in the name of their own interests.

For these reasons, confrontation and conflict are increasingly common among societies, which are one of the possible ways to improve life ${ }^{53}$. Europeans are threatened by the war against illegal immigration and terrorism. One party to this war does not have a classic army, while those who have it are not prepared for this fight. During a terrorist attack they can only reduce bloodshed, securing the area and neutralizing those who have made the act. Therefore, the battlefield that took place during the classical war has disappeared, and a fight began among people, against people, often with different tactics of fighting, with an opponent without state status ${ }^{54}$. Non-state entities (terrorist groups), thanks to the access to new technologies, are able to spread destruction on a scale previously reserved exclusively for governments ${ }^{55}$. Therefore, we observe that there is a fight going on in many parts of the world in which ${ }^{56}$ :

- there is no visible opponent (armed forces),

- it is necessary to conduct long-term operations (psychically and physically devastating the society $\left.-\mathrm{AF}^{57}\right)$,

- there are no classic objects of strikes for the armed forces,

- information becomes a strategic weapon, and the media an important instrument of modern struggle,

- there is an increase in the importance of small groupings (platoon and even team)

- the opponentis "without shape" or a permanent form of organization of activities

- The opponent uses every opportunity and form of attack.

In reference to the observations of Ryszard Szpyra, the author shares his view that in a new crisis situation, in which states and their societies were found, armies should be transformed. Some of them should be devoted to the fight against the greatest threat to global peace, which is contemporary terrorism, which leads the fight of all against all, a brutal battle in which everything can be used as a weapon.

In order to prevent human and material losses, it would be necessary to prepare the society for cooperation with the army and other institutions to manage crisis situations that are a consequence of the threat and lead to a break or significant violation of social ties ${ }^{58}$. If this factor does not work, Europeans will be the biggest losers in this war. Fear caused by terrorist attacks is not an isolated phenomenon, which paralyzes thoughts and rational actions. It creates a constant sense of terror, anxiety, fear about the present and the future. Hence, it is necessary to awaken the survival instinct among the population. It is necessary to unite forces. Those who have nothing to lose will win. It is about hundreds and even millions of immigrants coming to Europe for a better and safer life. Is this really true? Will we give them a part of our lives? Are we prepared for it? What will it end with? It is impossible to save all of Africa, taking over the burden of saving everyone from war or poverty. This kind of effort may end in a tragedy for one or the other, there will be no victors. Therefore, actions are necessary, "victory come to those who anticipate changes in the character of war, not to those who are waiting to adapt after the change" ${ }^{\prime 59}$.

\section{The NeEd To Prevent WAR And Prepare For It}

Therefore, in order for the state to be safe and able to protect its citizens against war threats, there is, first and foremost, a need to prevent war. This phase includes forces and state resources accumulated

\footnotetext{
${ }^{53}$ L. Wyszczelski, Visions of Wars ..., pg. 106.

${ }^{54}$ Ibidem, p. 108.

${ }^{55}$ J. S. Nye jr., International Conflicts ..., pg. 21.

${ }^{56}$ R. Szpyra, Art of war ..., p. 138.

${ }^{57} \mathrm{AF}$ - author's footnote.

${ }^{58}$ Act of April 26, 2007 on crisis management (Journal of Laws No. 89, item 589), art. 3, see also R. Jakubczak, J. Flis (ed.), National Security of Poland in the 21 st Century ..., pg. 415-416.

${ }^{59}$ G. Douchet, Italian general, founder of air combat theory, author of the work: Ruling in the air, Warsaw 1965.
} 
in the national security system, aimed at reducing the likelihood of its outbreak by ${ }^{60}$ : looking for alternative solutions to the causes of armed conflict, resolving conflicts peacefully before or after the implementation of forceful actions, increasing the importance of humanitarian and preventive operations and other than direct military intervention. It is also necessary to increase the influence of public opinion on parliaments and governments, in order to eliminate war from the civilized world, reduction of armaments and, consequently, the money spent on them. Such actions will contribute to improving the existence of societies and, as a consequence, discouragement to war.

During the implementation of the first phase, the second should be started - preparation for war, aimed at planning and organizing the defense and protective potential of the state to create conditions for reacting at the moment of its outbreak or limiting its effects. This applies above all to the development of an effective doctrine (concept) of a classical, asymmetric or hybrid war ${ }^{61}$. It is connected with the rational determination of the strategic goals possible to achieve, the assessment of threats and moral, intellectual, economic, financial and military resources of the state to fight against war threats. It is also important to acquire an ally, assess the conditions under which military operations will be carried out, including calculating profits, risks and losses. Effectiveness of the command systems and advantages in the information sphere if of major importance. It also involves safeguarding important buildings and devices of the critical infrastructure of the state against the negative impact of external forces. It is extremely important to protect the morale of the nation, as well as to recognize the culture of the community with which confrontation may occur, including the assessment of intra-state relations, economic opportunities, current capabilities of the armed forces and their possible intentions. In all this, the society must be prepared for the impact of evil, i.e. the fight against hypocrisy, heresy, bluff. Involve the society in acting in a completely different dimension of war - survival in the name of maintaining the human species.

\section{SUMMARY}

The article presents the views of well-known politicians in the field of attrition and collision of contemporary civilizations characterized by different levels of life of nations, predictable or surprising by their actions in relation to solving problems of a social, natural or religious nature. At present there are frequent violations of human rights, armed conflicts, terrorist attacks, there are threats related to the protection of the natural environment and life. These factors lead to the unjust distribution of goods, unemployment, social pathologies, and migration. The most dangerous is the fact that today's civilizations are falling apart, the nations in their structures are fighting with each other ${ }^{62}$. Most often it boils down to destroying and depriving of all values that satisfy human needs. This leads to mutual accusations in society, including dissatisfaction with the rulers, indifference and commitment to local, regional and global security.

Therefore, states (civilizations) should constitute the basic environment of human life, its future - the foundation of the common good. Today, one should consider whether the need for security is a common feature of all people? Who is threatened by this? Has everyone already forgotten what the effects war brings about, and especially the use of atomic bombs on Hiroshima and Nagasaki? What the "cold war" caused that lasted from the end of World War II for four consecutive decades, or the Chernobyl nuclear power plant disaster (1986) and Fukushima I (2011). History begins make full circles, threatening people with the use of atomic weapons with very high firepower - which can destroy our planet.

What will the destruction be like, will anyone survive? Who and what is it to serve - there will be no winners and no losers. We cannot allow this to happen. Civilizations have to shake off and realistically assess the situation. One cannot let wounds from the cold war to get inflamed - ruining all the previous effort to maintain common security around the world.

\footnotetext{
${ }^{60}$ The strategy of national safety of the Republic of Poland, Warsaw 2014.

${ }^{61}$ J.Pilżys, Department of Infantry of the Ministry of Military Affairs in the years 1921-1939, Szczecin 2012.

${ }^{62}$ F. Koneczny, About the greatness of a civilization...., pg. 304-305. According to the author "A nation must all belong, without slightest reservations, to the same civilization. A national association is a civilizational association".
} 


\section{REFERENCES}

[1] Balcerowicz B., About peace and war. Between an essay and a treaty, Warsaw 2013.

[2] Balcerowicz B., Peace and "unrest" on the threshold of the 21st century, Warsaw, 2002.

[3] Bloch J. G., Future war in technical, economic and political terms, Warsaw 2005.

[4] Bodziany M., Society and War. Faces of security in the XX and XXI century, Wrocław 2016.

[5] Brzeziński Z., Game plan. USA - USSR, Warsaw 1990, same: Great chess board, Warsaw 1999.

[6] Chmielarz P., War and the state. Yesterday and today, Warsaw 2010.

[7] Chocha B., Kaczmarek J., War and military doctrine. Selected problems, Warsaw 1980.

[8] Clausewitz Carl von, About war, cz. I, [Book 1-5], Warsaw 1958.

[9] Douchet G., Italian general, founder of air combat theory, author of the work: Ruling in the air, Warsaw 1965.

[10] Dworkin G., Nuclear intentions, [in:] T. Żuradzki, T. Kuniński (ed.), War ethics. Anthology of texts, Warsaw 2009.

[11] Gawor L., Feliks Konieczny's study of the multiplicity of civilizations, "Sofia", 2005, No. 5.

[12] Haliżak E., Interdependence of politics and economics in international relations, [in:] E. Haliżak, R. Kuźniar, G. Michałowska, S. Parzymies, J. Symonides and R. Zięba (ed.), International relations in the XXI century. Anniversary book in the event of the 30th anniversary of the Institute of International Relations at the University of Warsaw, Warsaw 2006.

[13] Hart L., Strategy. Indirect activities, transl. E. Biegański, Warsaw 1959.

[14] Huntington S.P., Collision of civilizations, (translated by H. Jankowska), Warsaw 2007.

[15] Jakubczak R., Flis J. (ed.), National Security of Poland in the 21st Century. Challenges and strategies, Warsaw 2006.

[16] Kissinger H., Diplomacy, Warsaw 2009, same: Crisis: Anatomy of two crises, Wrocław 2005.

[17] Kunikowski J., A Dictionary of Basic Terms in the field of defense knowledge, Warsaw 2002.

[18] Kuźniar Z., Barczyk K., The phenomenon of war from the point of view of the dialectical philosophy of G.F. Hegel, [in:] M. Bodziany (ed.) Society and war. Faces of security in the XX and XXI century, Wrocław 2016.

[19] Łoś R., Regina-Zacharski J., War in the modern world. Participants, goals, models, theories, Warsaw 2010.

[20] Makowski A., Maritime Wars - methodological problems, [in:] A. Aksamitowski, M. Franz (ed.), From the History of marine wars. Studies and sketches, Oświęcim 2015.

[21] Miśkiewicz B., War as the subject of historical research, [in:] K. Olejnik (ed.), War as the subject of historical research, Torun 2006.

[22] Mossor S., The presumed nature of the future war, "Bellona", 1936, No. 1.

[23] Nowak P., Conflict and war in the theory and practice of international relations, [in:] M. Cupryjak, P. Nowak, P. Ostrowski (ed.), Legal and historical approach to war and terrorism, Szczecin 2016.

[24] Nye jr. J. S., International Conflicts. Introduction to theory and history, Warsaw 2009.

[25] Ostaszewski P., International political relations. Outline of lectures, Warsaw 2010.

[26] Pawłowski J., Asymmetry - the consequence of turbulent military changes in the sphere of quantity and quality, [in:] Art of war in contemporary armed conflicts - changes and developmental tendencies, Materials from the scientific conference organized on October 20, 2006. Issued by AON in 2017.

[27] Pilżys J., Department of Infantry of the Ministry of Military Affairs in the years 1921-1939, Szczecin 2012.

[28] Pilżys J., System of security of monuments and national heritage of the Republic of Poland, [in:] J. Piątek, R. Podgórzańska (ed.) Selected aspects of security, Volume I, Szczecin 2007.

[29] Radecki E. W. (ed.), Lexicon of education for security, Szczecin 2015.

[30] Romański R., Military errors of Polish commanders, Warsaw 2013.

[31] Ryszka F., Politics and war, colloquial awareness and 20th century theories, State Publishing Institute, Warsaw 1975.

[32] Scientific Papers of the Military Academy of Land Forces, Wrocław, 2012, No. 2 (164).

[33] Sikorski W., Future war, its possibilities and character, and related issues of the defense of the country, Warsaw 1984, ed. II.

[34] Skibiński F., Considerations on the Art of War, Warsaw 1978.

[35] Smaczny H., Polish armed forces 1919-1939, Białystok 1999.

International Journal of Humanities Social Sciences and Education (IJHSSE) 
[36] Sun Tzu, Sun Pin, Art of War, Edition II, Gliwice 2008.

[37] The strategy of national safety of the Republic of Poland, Warsaw 2014.

[38] Toffler A., Toffler H., Revolutionary wealth, Przeźmierowo 2007.

[39] Toffler A., Toffler H., War and anti-war, how to survive on the threshold of the 21st century, Warsaw 1997.

[40] Walzer M., Just and unjust wars, Warsaw 2010.

[41] Wyszczelski L, War and the art of war in the Western European military theory of the sixteenth and seventeenth centuries, "Bellona Quarterly", 2014, No. 3.

[42] Wyszczelski L., Visions of wars after the disintegration of the bipolar political and military system of the world, [in:] " Bellona Quarterly", 2016, No. 1 (684).

[43] Zacharski J. R., War in the modern world. Participants. Objectives. Models. Theories, Łódź 2014.

\section{AUTHOR'S BIOGRAPHY}

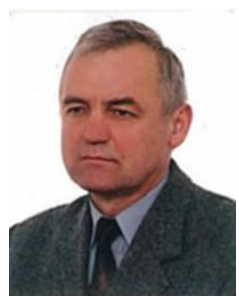

Jan PILZYS - a graduate of the Officers' School of the Anti-aircraft Defense Forces in Koszalin. In 2001, he completed his doctoral studies at the AON in Warsaw at the Military Historical Institute, obtaining a Ph.D. in humanities in the major of history. The creator of many concepts of education, training and teaching programs. The author of methodological elaborations, guides, scripts, monographs of the Military Officers' School of the Anti-aircraft Defense Forces.

Since 2004, he has been an academic teacher at the University of Szczecin. He published: Crisis Management (Szczecin 2007), Lexicon of economic security (Szczecin 2011), Planning in crisis management (Szczecin 2012), Department of Infantry of the Ministry of Military Affairs in the years 1921-1939 (Szczecin 2012), Antiaircraft defense forces in the years 1918-2013. Rules of tactical operations (Szczecin 2014), Communication in crisis management and rescue systems in Poland theory and practice (Szczecin 2015). He is a co-author of the work: Defense Policy of Poland and its Armed Forces in the years 1945-1980 (Szczecin 2006). In the years 2004-2017, he published dozens of articles on historical issues, education and national security.

Citation: Jan Pilzys. "Local Wars Threatening World Peace". International Journal of Humanities Social Sciences and Education (IJHSSE), vol 5, no. 2, 2018, pp. 76-87 doi: http://dx.doi.org/10.20431/23490381.0502009.

Copyright: (C) 2018 Authors. This is an open-access article distributed under the terms of the Creative Commons Attribution License, which permits unrestricted use, distribution, and reproduction in any medium, provided the original author and source are credited. 